\title{
FITOREMEDIASI LIMBAH MERKURI MENGGUNAKAN TANAMAN DAN SISTEM REAKTOR
}

\author{
Sendy B. Rondonuwu ${ }^{1)}$ \\ ${ }^{1)}$ PS Biologi FMIPA Unsrat, Jl. Kampus Unsrat Manado \\ e-mail: rondonuwu64@yahoo.com
}

\begin{abstract}
ABSTRAK
Fitoremediation menggunakan tanaman teknologi yang lebih efektif dan efisien untuk membersihkan lingkungan tercemar merkuri Penelitian ini bertujuan untuk tanaman merkuriperedam dan untuk menguji kemampuan aktivitas tanaman dalam mengurangi merkuri. Percobaan dilakukan di laboratorium FMIPA-UNSRAT. Hasil penelitian menunjukkan bahwa beberapa tanaman akumulasi $\mathrm{Hg}$ uch sebagai Typha sp. (84.18\%), Hydrilla verticillata $(83,96 \%)$, Ipomoae aquatic (83,84\%), Eichhornia crassipes (81,19\%), Nelubium nelumbo (80,78\%).
\end{abstract}

Kata kunci: Fitoremediation, tanaman resisten mercury, uji kemampuan

\section{PHYTOREMEDIATION WASTE MERCURY USING PLANT AND SYSTEM REACTOR}

\begin{abstract}
Fitoremediation using plant is a more effective and efficient technology for cleaning of mercury contaminated environment This experiment was aimed to mercury-reducer plant and to test the ability of the plant activity in reducing mercury. The experiment was carried out in the laboratory of FMIPA-UNSRAT. The result showed that some plant accumulated $\mathrm{Hg}$ uch as Typha sp. (84.18\%), Hydrilla verticillata (83,96\%), Ipomoae aquatic $(83,84 \%)$, Eichhornia crassipes (81,19\%), Nelubium nelumbo (80,78\%).
\end{abstract}

Keywords: Fitoremediation, Mercury-resistant plant, test the ability

\section{PENDAHULUAN}

Fitoremediasi berasal dari bahasa Yunani Kuno yaitu nabati/ tanaman, dan bahasa Latin yaitu remedium (memulihkan keseimbangan atau perbaikan); menggambarkan pengobatan masalah lingkungan (bioremediasi) melalui penggunaan tanaman yang mengurangi masalah lingkungan tanpa perlu menggali bahan kontaminan dan membuangnya di tempat lain. Fitoremediasi adalah penggunaan tumbuhan untuk menghilangkan polutan dari tanah atau perairan yang terkontaminasi. Akhir-akhir ini teknik reklamasi dengan fitoremediasi mengalami perkembangan pesat karena terbukti lebih murah dibandingkan metode lainnya, misalnya penambahan lapisan permukaan tanah. Fitoremediator tersebut dapat berupa herba, semak bahkan pohon. Semua tumbuhan mampu menyerap logam dalam jumlah yang bervariasi, tetapi beberapa tumbuhan mampu mengakumulasi unsur logam tertentu dalam konsentrasi yang cukup tinggi. Sudah banyak hasil penelitian yang membuktikan keberhasilan penggunaan tumbuhan untuk remediasi dan tidak sedikit tumbuhan yang dibuktikan sebagai hiperakumulator adalah species yang berasal dari daerah tropis. Species tersebut diantaranya Thlaspi calaminare untuk seng (Zn), Thlaspi caerulescens untuk kadmium (Cd), Aeolanthus biformifolius untuk tembaga $(\mathrm{Cu})$, Phylanthus serpentines untuk nikel (Ni), Haumaniastrum robertii untuk kobalt (Co) Astragalus racemosus untuk selesium (Se), dan Alyxia rubricaulis untuk mangan (Mn) (Wise et. al., 2000). Selain itu Brachiaria mutica untuk air raksa $(\mathrm{Hg})$ (Kartawinata, 2002, komunikasi pribadi). Menurut Baker dan Brooks (1989) bahwa sedikitnya ada satu taksa tumbuhan yang 
bersifat hiperakumulator untuk kadmium, 28 taksa untuk kobalt, 37 taksa untuk tembaga, sembilan taksa untuk magnesium, 317 taksa untuk nikel dan 11 taksa untuk seng.

\section{METODE PENELITIAN}

\section{Lokasi dan Waktu Penelitian}

Lokasi penelitian di pertambangan emas rakyat tanpa izin di desa TalawaanTatelu terletak di Kabupaten Minahasa Utara, arah utara dari pulau Sulawesi. Pelaksanaan kegiatan penelitian dilakukan di beberapa laboratorium. Kegiatan identifikasi tanaman pereduksi merkuri dan pengolahan air limbah merkuri pada reaktor di Laboratorium Fakultas MIPA Universitas Sam Ratulangi. Pengujian sampel dilakukan di Laboratorium Air dan Lingkungan Baristand Industri Manado. Penelitian telah dilaksanakan Mei 2013 sampai dengan Juli 2013.

\section{Bahan dan Alat Penelitian}

Sampel untuk analisis merkuri lingkungan pertambangan berupa air dan tanah di sekitar lokasi di Talawaan-Tatelu, Kabupaten Minahasa Utara, Provinsi Sulawesi Utara. Tanaman yang akan digunakan yaitu: Eichhornia crassipes, Typha $s p$, Nelubium nelumbo, Ipomoae aquatic, Hydrilla verticillata. Peralatan yang digunakan dalam reaktor biofilm adalah : (1) reaktor yang terbuat dari kaca dengan ukuran ketebalan $5 \mathrm{~mm}$ dengan ukuran $20 \mathrm{~cm} \times 20$ $\mathrm{cm} \times 15 \mathrm{~cm}$ (volume 6 liter) sebanyak 6 buah; (2) kran air; (3) slang silikon; (4) lem kaca (5) lem plastik. Peralatan yang digunakan untuk analisis merkuri adalah tabung erlenmeyer dengan berbagai ukuran, pipet, buret, gelas ukur dan Cold Vapour Atomic Absorption Spektrofotometer (CV-AAS).

\section{Pelaksanaan Penelitian}

Pengoperasian reaktor dilakukan dengan tahapan: (1) Wadah A yang berisi air limbah merkuri dialirkan ke reaktor B, C, D, $\mathrm{E}, \mathrm{F}$ yang berisi masing-masing tanaman Eichhornia crassipes, Typha sp, Nelubium nelumbo, Ipomoae aquatic, Hydrilla verticillata. Pengambilan sampel air pada hari pertama, ketiga, dan keenam masingmasing sebanyak $10 \mathrm{ml}$. Pengambilan sampel dengan 3 ulangan. Pemberian kadar merkuri dengan 4 perlakuan yaitu: $0 \mathrm{ppm}, 10 \mathrm{ppm}, 25$ ppm, dan $50 \mathrm{ppm}$.

Variabel yang diteliti adalah: (1) kadar merkuri dalam wadah A sebelum diberi perlakuan; (2) kadar merkuri dalam reaktor B yang berisi tanaman Eichhornia crassipes, reaktor C berisi Typha $s p$, reaktor D berisi Nelubium nelumbo, reaktor E berisi Ipomoae aquatic, reaktor $\mathrm{F}$ berisi Hydrilla verticillata.; (3) efisiensi penurunan kadar merkuri dalam masing-masing reaktor $\mathrm{B}, \mathrm{C}, \mathrm{E}$, dan $\mathrm{F}$ dalam prosentase.

\section{HASIL DAN PEMBAHASAN}

\section{Kemampuan mereduksi Hg dalam Lahan Basah Buatan}

Merkuri merupakan salah satu jenis logam berat yang termasuk kategori limbah Bahan Berbahaya dan Beracun (B3) karena dapat membahayakan makhluk hidup dan mencemari lingkungan. Air limbah yang mengandung merkuri harus diolah terlebih dahulu agar mempunyai kualitas yang sama dengan kualitas air lingkungan yang tidak bersifat toksik bagi makhluk hidup. Fitoremediasi merupakan sistem dimana tanaman tertentu bekerja sama dengan mikroorganisme dalam media yang dapat mengubah zat berbahaya menjadi kurang atau tidak berbahaya bagi lingkungan. Sifat hipertoleran terhadap logam berat adalah kunci karakteristik yang mengindikasikan sifat hiperakumulator suatu tumbuhan.

Suatu tumbuhan dapat disebut hiperakumulator apabila memiliki karakterkarakter sebagai berikut: (1) Tumbuhan memiliki tingkat laju penyerapan unsur dari tanah yang lebih tinggi dibanding tanaman lainnya, (2) Tumbuhan dapat mentoleransi unsur dalam tingkat yang tinggi pada jaringan akar dan tajuknya, dan (3) Tumbuhan memiliki laju translokasi logam berat dari akar ke tajuk yang tinggi sehingga akumulasinya pada tajuk lebih tinggi dari pada akar (Brown et al, 1995).

Dalam penelitian ini digunakan limbah sintesis yang mengandung $10 \mathrm{ppm}$ $\mathrm{HgCl}_{2}$ atau setara dengan $7.39 \mathrm{ppm} \mathrm{Hg}$ serta tidak menggunakan bakteri pereduksi merkuri. Rancangan dalam percobaanini menggunakan 4 buah reaktor dengan ukuran panjang $20 \mathrm{~cm}$, lebar $20 \mathrm{~cm}$ dan tinggi $15 \mathrm{~cm}$. Tanaman Eichhornia crassipes, Typha sp, 
Nelubium nelumbo, Ipomoae aquatic, Hydrilla verticillata ditanam pada reaktor yang berisi batuan, pasir, dan tanah gembur dengan perbandingan masing-masing 30\% selama 7 hari. Kelima tanaman dipelihara sehingga mencapai kondisi segar dan siap untuk diberi perlakuan. Pengambilan sampel sebanyak $10 \mathrm{ml}$ pada reaktor A yang berisi limbah sintetik $\mathrm{HgCl}_{2}$ dilakukan pada hari ke1 dengan 3 ulangan. Selanjutnya limbah sintesis merkuri dialirkan ke reaktor $\mathrm{B}, \mathrm{C}, \mathrm{D}$, $\mathrm{E}$, dan $\mathrm{F}$ yang masing-masing berisi tanaman Eichhornia crassipes, Typha sp, Nelubium nelumbo, Ipomoae aquatic, Hydrilla verticillata. Pengambilan sampel sebanyak 10 $\mathrm{ml}$ pada reaktor $\mathrm{B}, \mathrm{C}, \mathrm{D}, \mathrm{E}$, dan $\mathrm{F}$ dilakukan pada hari ke-4 dengan 3 ulangan.

Kemampuan mereduksi merkuri (\%) dalam reaktor lahan basah buatan selama 3 hari dari tanaman Typha sp. sebesar 84.18\%; tanaman Eichhornia crassipes sebesar 81,19\%; Nelubium nelumbo sebesar 80,78\%; Ipomoae aquatic sebesar 83,84\%; dan Hydrilla verticillata sebesar $83,96 \%$. Hasil penelitian menunjukkan bahwa tanaman Typha sp., Ipomoae aquatic, dan tanaman Hydrilla verticillata memiliki kemampuan mereduksi merkuri lebih tinggi dibandingkan tanaman Nelubium nelumbo dan Eichhornia crassipes, karena berdasarkan kemampuan hiperakumulator. Tanaman Typha sp., Ipomoae aquatic, dan tanaman Hydrilla verticillata termasuk jenis tanaman mencuat di permukaan air (emergent) dan akarnya tenggelam (amphibious) sehingga memiliki kemampuan lebih tinggi dalam mengakumulasi logam berat termasuk merkuri; sedangkan tanaman Nelubium nelumbo dan Eichhornia crassipes termasuk jenis tanaman mengambang (floating) (Khiatuddin, 2003). Hasil uji statistik menunjukkan tidak berbeda nyata satu dengan lainnya pada $p<0,05$. Dan dapat disimpulkan bahwa ke-5 masing-masing tanaman yaitu tanaman Typha sp., Ipomoae aquatic, Hydrilla verticillata, Nelubium nelumbo, dan Eichhornia crassipes dapat digunakan pada sistem lahan basah buatan dalam mereduksi merkuri.

\section{Tanaman Typha sp.}

Tanaman Typha identik dengan tanaman untuk taman gaya modern atau sebagai tanaman taman minimalis. Kita sering menyebutnya tifa. Tifa memberi aksen unik pada sebuah taman. Kelompok tanaman rumput ini dikenal sebagai bagian dari keluarga alang-alang. Maka, typha tumbuh dan berkembang dalam sebuah koloni. Akar tanaman ini berupa rhizome. Fisiknya kuat untuk menahan erosi tanah. Lokasi pertumbuhannya berupa lahan basah, seperti pinggiran danau atau rawa-rawa. Tanaman Typha memiliki banyak spesies. Spesies yang paling banyak penyebarannya adalah Typha latifolia dan Typha angustifolia.

Hasil penelitian menunjukkan bahwa tanaman typha dalam bioreaktor mampu mereduksi merkuri sebesar 98,03\% sampai dengan $99,08 \%$ selanjutnya tanaman eceng gondok sebesar $95,57 \%$ sampai dengan 97,76\%. Tanaman typha (Thypha latifolia) dan tanaman eceng gondok (Eichhornia crassipes) termasuk tanaman yang memiliki kemampuan tinggi untuk mengangkut bahan pencemar yang terdapat di alam. Ke-2 tanaman ini memiliki kemampuan yang disebut dengan hiperakumulator, yaitu relatif tahan terhadap berbagai macam bahan pencemar seperti logam-logam berat $\mathrm{Hg}, \mathrm{Pb}$, $\mathrm{Cn}, \mathrm{Mn}, \mathrm{Mg}$ dan mampu mengakumulasikannya dalam jaringan dengan jumlah yang cukup besar. Logam berat yang terlarut dalam air akan berpindah ke dalam sedimen jika berikatan dengan materi organik bebas atau materi organik yang melapisi permukaan sedimen, dan penyerapan langsung oleh permukaan partikel sedimen (Reddy, 1990; Crawford and Crawford, 2005).

\section{Tanaman Eceng gondok (Eichhornia crassipes)}

Eceng gondok atau enceng gondok (Latin: Eichhornia crassipes) adalah salah satu jenis tumbuhan air mengapung. Selain dikenal dengan nama eceng gondok, di beberapa daerah di Indonesia, eceng gondok mempunyai nama lain seperti di daerah Palembang dikenal dengan nama Kelipuk, di Lampung dikenal dengan nama Ringgak, di Dayak dikenal dengan nama Ilung-ilung, di Manado dikenal dengan nama Tumpe. Eceng gondok pertama kali ditemukan secara tidak sengaja oleh seorang ilmuwan bernama Carl Friedrich Philipp von Martius, seorang ahli botani berkebangsaan Jerman pada tahun 1824 ketika sedang melakukan ekspedisi di Sungai Amazon Brasil. Eceng gondok memiliki kecepatan tumbuh yang tinggi 
sehingga tumbuhan ini dianggap sebagai gulma yang dapat merusak lingkungan perairan. Eceng gondok dengan mudah menyebar melalui saluran air ke badan air lainnya.

Walaupun eceng gondok dianggap sebagai gulma di perairan, tetapi sebenarnya ia berperan dalam menangkap polutan logam berat. Rangkaian penelitian seputar kemampuan eceng gondok oleh peneliti Indonesia antara lain oleh Widyanto dan Susilo (1977) yang melaporkan dalam waktu 24 jam eceng gondok mampu menyerap logam kadmium $(\mathrm{Cd})$, merkuri $(\mathrm{Hg})$, dan nikel (Ni), masing- masing sebesar 1,35 $\mathrm{mg} / \mathrm{g}, 1,77 \mathrm{mg} / \mathrm{g}$, dan $1,16 \mathrm{mg} / \mathrm{g}$ bila logam itu tak bercampur. Eceng gondok juga menyerap $\mathrm{Cd} 1,23 \mathrm{mg} / \mathrm{g}, \mathrm{Hg} 1,88 \mathrm{mg} / \mathrm{g}$ dan Ni $0,35 \mathrm{mg} / \mathrm{g}$ berat kering apabila logamlogam itu berada dalam keadaan tercampur dengan logam lain. Lubis dan Sofyan (1986) menyimpulkan logam chrom (Cr) dapat diserap oleh eceng gondok secara maksimal pada $\mathrm{pH}$ 7. Dalam penelitiannya, logam $\mathrm{Cr}$ semula berkadar $15 \mathrm{ppm}$ turun hingga 51,85 persen. Selain dapat menyerap logam berat, eceng gondok dilaporkan juga mampu menyerap residu pestisida.

Merkuri merupakan salah satu jenis logam berat yang termasuk kategori limbah Bahan Berbahaya dan Beracun (B3) karena dapat membahayakan makhluk hidup dan mencemari lingkungan. Air limbah yang mengandung merkuri harus diolah terlebih dahulu agar mempunyai kualitas yang sama dengan kualitas air lingkungan yang tidak bersifat toksik bagi makhluk hidup.

Fitoremediasi merupakan sistem dimana tanaman tertentu bekerja sama dengan mikroorganisme dalam media yang dapat mengubah zat berbahaya menjadi kurang atau tidak berbahaya bagi lingkungan. Tujuan dari penelitian ini adalah untuk mengetahui besarnya efisiensi optimum penurunan konsentrasi limbah yang mengandung $\mathrm{Hg}$ oleh tanaman eceng gondok (Eichhornia Crassipes), serta melihat efek toksisitas logam merkuri terhadap tumbuhan uji, dan membandingkannya dengan penelitian-penelitian sebelumnya yang menggunakan limbah yang lebih kompleks.

Pada penelitian ini, limbah yang digunakan adalah limbah hasil keluaran dari proses adsorpsi karbon aktif. Penelitian ini menggunakan reaktor batch yang terbuat dari tripleks dan

dilapisi plastic sebagai lapisan kedap air dengan ukuran reaktor $1 \mathrm{~m}$ x $0,5 \mathrm{~m}$ dan dilakukan di dalam rumah kaca. Konsentrasi limbah yang diuji adalah $1 \mathrm{ppm}$ dan $0,5 \mathrm{ppm}$ dengan variasi waktu penelitian hari ke- 0 , hari ke-3, hari ke-6, hari ke-9, hari ke-12, dan hari ke-15.

Pengujian $\mathrm{Hg}$ yang digunakan pada penelitian ini yaitu metode Mercury Analyzer. Dari hasil Penelitian diperoleh bahwa tanaman eceng gondok dapat menurunkan limbah yang mengandung $\mathrm{Hg}$ buatan dengan efisiensi penurunan optilam pada konsentrasi 0,5 ppm sebesar 99,72\% dan lebih efektif jika dibandingkan dengan penelitian-penelitian sebelumnya yang menggunakan limbah yang lebih kompleks (Limbah Cair Laboratorium).

Pencemaran air akibat kontaminasi logam berat dapat menyebabkan turunnya kualitas air selain itu juga dapat meracuni manusia. Salah satu cara untuk mengurangi pencemaran air akibat logam berat yaitu dengan pemanfaatan biota air, salah satunya adalah eceng gondok.

Penelitian ini dilakukan untuk mengetahui seberapa besar kemampuan eceng gondok dalam menyerap campuran logam arsen, kadmium dan merkuri. Pada penelitian ini eceng gondok (Eichhornia crassipes) ditumbuhkan dalam air yang mengandung campuran logam arsen, kadmium dan merkuri dengan konsentrasi masing-masing $3 \mathrm{mg} / \mathrm{L}$ selama 72 jam. Pengambilan eceng gondok dilakukan pada jam ke-24, 48 dan 72. Metode yang digunakan adalah analisis aktivasi neutron menggunakan standar arsen, kadmium dan merkuri dan hasilnya dinyatakan dalam $\mu \mathrm{g} / \mathrm{g}$ berat kering. Pada waktu 24 jam kadar arsen sebesar 282,2541 $\mu \mathrm{g} / \mathrm{g}$, kadmium 272,0598 $\mu \mathrm{g} / \mathrm{g}$ dan merkuri 7,2040 $\mu \mathrm{g} / \mathrm{g}$; pada waktu 48 jam kadar arsen sebesar 401,7782 $\mu \mathrm{g} / \mathrm{g}$, kadmium 351,1447 $\mu \mathrm{g} / \mathrm{g}$ dan merkuri $15,2580 \mu \mathrm{g} / \mathrm{g}$; pada waktu 72 jam kadar arsen sebesar 443,1964 $\mu \mathrm{g} / \mathrm{g}$, kadmium sebesar $701,4444 \mu \mathrm{g} / \mathrm{g}$ dan merkuri $20,0223 \mu \mathrm{g} / \mathrm{g}$. Dari hasil tersebut menunjukkan bahwa semakin lama pertumbuhan eceng gondok dalam air maka semakin tinggi arsen, kadmium dan merkuri yang diserap dan diakumulasi oleh eceng gondok. 


\section{Tanaman Nelubium nelumbo}

Tanaman air menahun yang indah, asli dari daratan Asia. Teratai dibudidayakan diperairan dan kolam, kadang ditemukan tumbuh liar dirawa-rawa. Tanaman air yang tumbuh tegak, rimpang tebal bersisik, tumbuh menjalar. Daun dan bunga keluar langsung dari rimpangnya yang terikat pada lumpur didalam kolam. Helaian daun lebar dan bulat, disangga oleh tangkai yang panjang dan bulat berdiameter $0,5-1 \mathrm{~cm}$, panjangnya 75-150 $\mathrm{cm}$. Daun menyembul keatas permukaan air, menjulang tegak seperti perisai. Permukaan daun berlilin, warnanya hijau keputihan, tepi rata, bagian tengah agak mencekung, tulang daun tersebar dari pusat daun kearah tepi, berdiameter $30-50 \mathrm{~cm}$. Bunganya harum, tumbuh menjulang diatas permukaan air dengan tangkai bulat panjang dan kokoh, panjang tangkai bunga 75-200 $\mathrm{cm}$. Diameter bunga $15-25 \mathrm{~cm}$, benag sari banyak kepala sari kuning, mahkota bunga lebar, ada yang engkel dan ada yang dobel dengan warna merah jambu, putih dan kuning. Bunga mekar sehari penuh dari pagi sampai sore hari. Setelah layu mahkota bunga berguguran sampai akhirnya tersisa dasar bunga yang akan menjadi bakal buah, bentuknya seperti kerucut terbalik dengan permukaan datar semacam spons dan berlubang-lubang berisi 15-30 biji, warnanya hijau kekuningan, kemudian hijau dan akhirnya coklat hitam, garis tengah $6-11 \mathrm{~cm}$. Biji bentuknya bulat seperti kacang tanah, terdapat dalam lubanglubang buah yang berbentuk seperti sarang tawon. Biji yang sudah tua warnanya hijau kehitaman, umurnya kira-kira 1 bulan sejak bunganya mekar. Daunnya biasa dipakai sebagai bahan pembungkus, rimpang muda, dan biji bisa dimakan. Pemeluk agama Budha menganggap bunga ini sebagai lambang kesucian, tercermin dalam berbagai lukisan dan patung yang menggambarkan Sang Budha sedang duduk bersemedi diatas bunga teratai.

Kandungan kimia teratai diantaranya Bunga: Quercetin, Iuteolin, Isoquercitin, Kaemferol. Benangsari: Quercetin, Luteolin, Isoquercitrin, Galuteolin, juga terdapat Alkaloid. Penyangga Bunga (receptacle): Protein, Lemak, Karbohidrat, Caroten, Asam Nikotinat, Vitamin B1, B2, C dan sedikit mengandung nelumbine. Biji: Kaya akan pati, juga mengandung raffinose, protein, lemak, karbohidrat, kalsium, phospor, dan besi. Kulit biji teratai mengandung nuciferine, oxoushinsunine, N-norarmapavine. Tunas Biji teratai: Liensinine, insoliensinine, neferine, nuciferine, pronuciferine, lotusine, methylcorypalline, demethylcoclaurine, galuteolin, hyperin, rutin. Rimpang: Pati, protein, asparagine, Vitamin C. Selain itu juga mengandung catechol, d-gallocatechol, neoclorogenic acid, leucocyanidin, leucodelphinidin, peroxidase, dll. Akar: Zat tannic dan asparagine. Daun: Roemerin, nuciferine, nornuciferin, armepavin, pronuciferin, N-nornuciferin, $\mathrm{D}-\mathrm{N}$ methylcoclaurine, anonaine, liriodenine, quercetin, isoquercitrin, nelumboside, citric acid, tartaric acid, malic acid, oxalic acid, succinic acid, zat tannic dll. Dasar daun teratai: Roemerine, nuciferine, resin dan nornuciferine. Tangkai Daun: Roemerine, nornuciferine, resin dan zat tannic. Oxoushinesunine yang terdapat pada kulit biji teratai berkhasiat menekan perkembangan kanker hidung dan tenggorokan, sedangkan biji dan tangkai teratai berkhasiat anti hypertensi. Teratai dapat digunakan sebagai herbal penyembuh hipertensi dan sejumlah penyakit lain seperti diare, disentri, keputihan, kanker nasopharynx, demam, insomnia, muntah darah, mimisan, batuk darah, sakit jantung, beri-beri, sakit kepala, berak dan kencing darah, anemia, ejakulasi.

\section{Tanaman Ipomoae aquatic}

Kangkung (Ipomoea aquatica Forsk.) juga dikenal sebagai Ipomoea reptans Poir1. merupakan sejenis tumbuhan yang termasuk jenis sayur-sayuran dan di tanam sebagai makanan. Kangkung banyak dijual di pasarpasar. Kangkung banyak terdapat di kawasan Asia dan merupakan tumbuhan yang dapat dijumpai hampir di mana-mana terutama di kawasan berair.Kangkung juga merupakan makanan salah satu spesies hewan Chersina, atau kura-kura. Ada dua jenis penanaman diusahakan yaitu: kering dan basah. Dalam keduanya, sejumlah besar bahan organik (kompos) dan air diperlukan agar tanaman ini dapat tumbuh dengan subur. Dalam penanaman kering, kangkung ditanam pada jarak 5 inci pada batas dan ditunjang dengan kayu sangga. Kangkung dapat ditanam dari biji benih atau keratan akar. Ia sering ditanam pada semaian sebelum dipindahkan di kebun. Daun kangkung dapat dipanen setelah 6 minggu ia ditanam. Jika penanaman basah 
digunakan, potongan sepanjang 12-inci ditanam dalam lumpur dan dibiarkan basah. Semasa kangkung tumbuh, kawasan basah ditenggelami pada tahap 6 inci dan aliran air perlahan digunakan. Aliran air ini kemudian dihentikan apabila tanah harus digemburkan. Panen dapat dilakukan 30 hari setelah penanaman. Apabila pucuk tanaman dipetik, cabang dari tepi daun akan tumbuh lagi dan dapat dipanen setiap 7-10 hari. Semasa berbunga, pucuk kangkung tumbuh dengan lambat, tetapi pembajakan tanah dan panen cenderung menggalakkan lebih banyak daun yang dihasilkan.

Ada dua bentuk kangkung. Kangkung mempunyai daun yang licin dan berbentuk mata panah, sepanjang 5-6 inci. Tumbuhan ini memiliki batang yang menjalar dengan daun berselang dan batang yang menegak pada pangkal daun. Tumbuhan ini bewarna hijau pucat dan menghasilkan bunga bewarna putih, yang menghasilkan kantung yang mengandung empat biji benih. Terdapat juga jenis daun lebar dan daun tirus. Hampir keseluruhan tanaman muda dapat dimakan. Karena kangkung tua berserat kasar, pucuk yang muda lebih digemari. Ia dapat dimakan mentah atau dimasak seperti bayam. Kangkung sering juga digoreng sebagai cah. Plecing kangkung merupakan menu yang terkenal dari daerah Lombok.

\section{Tanaman Hydrilla verticillata}

Hydrilla (rumput air) adalah jenis tanaman air yang hanya terdiri dari satu spesies. Meskipun beberapa ahli botani membaginya menjadi beberapa spesies yaitu : $H$. asiatica, $H$. japonica, H.lithuanica, dan H.ovalifolica. Hydrilla verticillata memiliki rimpang putih kekuningan yang tumbuh di sedimen bawah air sampai dengan kedalaman $2 \mathrm{~m}$. Panjang batang yang tumbuh sekitar 1-2 $\mathrm{m}$. Hydrilla adalah tanaman produktif dalam air yang dapat tumbuh dengan cepat dan dapat berkembang dalam air dari beberapa sentimeter sampai 20 meter. Daun kecil (1 / 2 - 3 / 4 inci) berbentuk segitiga-lancip yang berada di ulir dari 4-8 daun di sepanjang batang dengan lebar masing-masing daun 5$20 \mathrm{~mm}$ dan panjang lebar 0,7-2 mm. Tidak seperti tanaman air asli, daun Hydrilla memiliki tepi bergerigi atau duri kecil menonjol dan seperti gundukan di sepanjang pelepah di bagian bawah. Hydrilla biasanya hijau, tapi karena berada di bawah sinar matahari menjadi kuning atau coklat. Batang bercabang banyak dekat permukaan dan tumbuh secara horisontal, membentuk tikar padat vegetasi. Umbi kecil ada di dasar akar tanaman. Pelepah daun Hydrilla sering kemerahan jika segar. Tanaman air ini termasuk monoecious, yaitu bunga jantan dan betina diproduksi secara terpisah di sebuah tanaman tunggal. Bunga-bunga kecil dengan tiga sepal dan tiga kelopak, panjang kelopak 3-5 mm, transparan dengan garis-garis merah. Tetapi ada pula yang termasuk dioecious, yaitu tumbuhan yang terdiri dari hanya tumbuhan androecious (bunga hanya mempunyai stamen atau benang sari saja, dan disebut bunga jantan) dan Ginoecious (bunga hanya mempunyai karpel atau putik saja dan disebut bunga betina).

Hydrilla adalah tumbuhan Spermatophyta yang hidup di air, sehingga ia memiliki bentuk adaptasi yang berbeda dengan Spermatophyta darat. Dinding selnya tebal untuk mencegah osmosis air yang dapat menyebabkan lisisnya sel. Sel Hydrilla berbentuk segi empat beraturan yang tersusun seperti batu bata. Memiliki kloroplas dan klorofil yang terdapat didalamnya. Pada daun Hydrilla, dapat pula diamati proses aliran sitoplasma, yaitu pada bagian sel - sel penyusun ibu tulang daun yang memanjang di tengah - tengah daun. Pada hydrilla juga terdapat trikoma yang berfungsi untuk mencegah penguapan yang berlebihan. Hydrilla merupakan tumbuhan tenggelam, biasanya berakar, hidup selamanya di air dengan panjang batang mencapai $9 \mathrm{~m}$ (30 kaki). Berasal dari rimpang dan berujung dengan umbi kecil. Hydrilla memiliki resistensi yang tinggi terhadap salinitas (> 910ppt) dibandingkan dengan tanaman air lain yang terkait di air tawar. Hydrilla mirip beberapa tanaman air lainnya, termasuk Egeria dan Elodea.

\section{KESIMPULAN}

Fitoremediasi merupakan sistem dimana tanaman tertentu bekerja sama dengan mikroorganisme dalam media yang dapat mengubah zat berbahaya menjadi kurang atau tidak berbahaya bagi lingkungan. Merkuri merupakan salah satu jenis logam berat yang termasuk kategori limbah Bahan Berbahaya dan Beracun (B3) karena dapat 
membahayakan makhluk hidup dan mencemari lingkungan. Air limbah yang mengandung merkuri harus diolah terlebih dahulu agar mempunyai kualitas yang sama dengan kualitas air lingkungan yang tidak bersifat toksik bagi makhluk hidup.

Kemampuan mereduksi merkuri (\%) dalam reaktor lahan basah buatan selama 3 hari dari tanaman Typha sp. sebesar 84.18\%; tanaman Eichhornia crassipes sebesar 81,19\%; Nelubium nelumbo sebesar 80,78\%; Ipomoae aquatic sebesar 83,84\%; dan Hydrilla verticillata sebesar 83,96\%.

Hasil penelitian menunjukkan bahwa tanaman Typha sp., Ipomoae aquatic, dan tanaman Hydrilla verticillata memiliki kemampuan mereduksi merkuri lebih tinggi dibandingkan tanaman Nelubium nelumbo dan Eichhornia crassipes, karena berdasarkan kemampuan hiperakumulator. Tanaman Typha sp., Ipomoae aquatic, dan tanaman Hydrilla verticillata termasuk jenis tanaman mencuat di permukaan air (emergent) dan akarnya tenggelam (amphibious) sehingga memiliki kemampuan lebih tinggi dalam mengakumulasi logam berat termasuk merkuri; sedangkan tanaman Nelubium nelumbo dan Eichhornia crassipes termasuk jenis tanaman mengambang (floating) (Khiatuddin, 2003). Hasil uji statistik menunjukkan tidak berbeda nyata satu dengan lainnya pada $p<0,05$. Dan dapat disimpulkan bahwa ke-5 masing-masing tanaman yaitu tanaman Typha sp., Ipomoae aquatic, Hydrilla verticillata, Nelubium nelumbo, dan Eichhornia crassipes dapat digunakan pada sistem lahan basah buatan dalam mereduksi merkuri.

\section{DAFTAR PUSTAKA}

Alloway, B.J and D.C. Ayres. 1997. Chemical Principles of Environmental Pollution, $2^{\text {nd }}$ Edition, Blackie Academic and Professional, Chapman \& Hall, London

Alfian Z. 2006. Merkuri: Antara Manfaat dan Efek Penggunaannya bagi Kesehatan Manusia dan Lingkungan. FMIPA USU. Medan.
Baker, A.J.M. and R.R. Brooks. 1989. Terrestrial higher plants which hyperaccumulate metal elements a reveiew of their distribution, ecology and phytochemistry. Biorecovery 1:81126.

Brown S.L., R.L.Chaney, J.S.Angle and A.J.M. Baker. 1995. Zink and Cadmium uptake by hyperaccumulator Thlaspi caerulescens grown in nutrient solution. Soil Science Society of America Journal 59:125-133.

Cluis, Corrinne.2004. Junk-Greedy Greens: Phytoremediation As a New Option For Soil Decontamination. Biotech Journal Vol 2: 61-67.

Darmono. 2006. Lingkungan Hidup dan Pencemaran. Hubungannya dengan Toksikologi Senyawa Logam. Penerbit Universitas Indonesia. Jakarta.

Ghosh, M., S. P. Singh. 2005. A Review on Phytoremediation of Heavy Metal and Utilization of Its By Product. Applied Ecology and Environmental Research. $3(2): 1-18$.

Henry, J. R. 2000. In An Overview of Phytoremediation of Lead and Mercury . NINEMS Report. Washington, D. C. PP.3 - 9 .

Hidayati, N. dan Saefudin. 2003. Potensi Hipertoleransi dan Serapan Logam Beberapa Jenis Tumbuhan terhadap Limbah Pengolahan Emas. [Laporan Teknik]. Bogor: Proyek Pengkajian dan Pemanfaatan Sumberdaya Hayati. Pusat Penelitian Biologi. LIPI.

ITCR. 2000. Technical and Regulatory Guidance Document, Pyhtotechnology . Interstate Technology Regulatory Council USA.

Juhaeti, T. dan F. Syarif. 2003. Studi Potensi Beberapa Jenis Tumbuhan Air untuk Fitoremediasi.[Laporan Teknik]. Bogor: Proyek Pengkajian dan Pemanfaatan Sumberdaya Hayati. Pusat Penelitian Biologi. LIPI. Bogor.

Kristanto P. 2002. Ekologi Industri. Universitas Indonesia Press. Jakarta.

Palapa TM. 2009. Bioremedasi Merkuri (Hg) Dengan Tumbuhan Air Pada Limbah Tambang Emas Rakyat Dimembe Kabupaten Minahasa Propinsi SulawesiUtara. Agritek 17(5):918-931. 
Tulalessy AH. 2005. Studi Pencemaran Merkuri pada Kawasan Penambangan Emas Rakyat Tatelu Sulawesi Utara [Disertasi]. Program Studi pengelolaan Sumber daya alam dan Lingkungan. Institut Pertanian Bogor. Bogor.

Wise D.L, D.J Trantolo, E.J Cichon., H.I. Inyang, and U. Stottmeister (eds.) 2000. Bioremediation of Contaminated Soils. New York: Marcel Dekker Inc. 